\title{
XXVIII. On the relative hardness of road materials
}

\section{B. Bevan Esq.}

To cite this article: B. Bevan Esq. (1831) XXVIII. On the relative hardness of road materials, Philosophical Magazine Series 2, 9:51, 164-165, DOI: 10.1080/14786443108647579

To link to this article: http://dx.doi.org/10.1080/14786443108647579

册 Published online: 01 Jun 2009.

Submit your article to this journal 준

Џ Article views: 3

Q View related articles $₫$ 


\section{Mr. Bevan on the relative Hardness of Road Materials.}

oxalic acid and three equivalents of water. If then exposed to a damp air, they increase slightly in weight by absorbing water hygrometrically, and its extent varies with the humidity of the atmosphere. In dry air at $70^{\circ} \mathrm{Fahr}$. the crystals lose some of their water of crystallization, and effloresce on the surface. The efflorescing temperature is thus very little above the ordinary heat of summer.

XXVIII. On the relative Hardness of Road Materials. By B. BEvan, Esq.

To the Editors of the Philosophical Magazine and Annals. Gentlemen,

I AM not aware of any published experiments on the relative hardness of road materials; and having for my own use examined a considerable variety of substances, as to their power of withstanding the percussion of a given weight, falling a few inches, I take the liberty of sending the results for your Magazine, if you think them sufficiently interesting. 'They were chiefly made in 1825 , and the weight used was of castiron, falling upon the several specimens broken to the ordinary size adopted in modern roads, resting upon stone, or upon iron.

If the weather to which these materials were exposed had no effect towards their destruction, the table hereby given would nearly express their relative value for the purpose of supporting the wear of a road. Such of the articles, therefore, which resist the action of frost and atmospheric moisture, and have the highest numbers, will be found the most valuable.

$$
\text { Remaining, yours truly, B. Bevan. }
$$

Mount Sorrel sienite ................................ 100

White marble .................................. 37, 31

Chert pebbles, much used in Middlesex* 34, 27, 52, 56, 55, 65

Quartz pebble in Bedfordshire gravel.............. $\quad 70$

Ferruginous sandstone of Bedfordshire ........... 20, 4.2

Hurlock, from lower chalk......................... $\quad 10$

Chalk..................................................

Granite, Scotch .................................. 110

Flint, yellow ................................. 33, 26

Greenstone or basalt, Quittlehill, near Coventry... $\quad 110$

Sandstone, soft ................................... $\quad 13,6$

Tile fragment .................................... 20

Gritstone, near Brixworth, Northamptonshire ... $\quad 48,60$

Limestone, near Bradwell, Bucks. ................. 5

* These pebbles, we believe, are merely rolled chalk-flints, altered in colour by the protoxide of iron contained in them having been converted into peroxide.-Enrs.

Dry 
Dry clay

Flint, black ..........................................

Portland stone, hard .................................

11,30

Quartz, white

Blue pebble, like Rowley rag........................

Coarse limestone, near Stilton, Huntingdonshire 105,110

Gritstone on road, near Leeds . .....................

Yorkshire paving-stone ...............................

Ketton, hard..............................................

Tetternhoe ................................................

Chert [?] from hills in Devonshire and Cornwall

Gray wether of Hertfordshire and Wiltshire ....

Grit of upper bed, Collyweston, near Stamford, Lincolnshire

Second bed, do.

Slate at do.............................................. 50

Stockton limestone, Warwickshire, (lias)............

Newbold-on-A von.....................do. ............. 36

Limestone of Stoke Cruerne, Northamptonshire 35

The steady pressure, without percussion, required to crush a piece of the marble weighing $\frac{1}{4} \mathrm{oz} .=600 \mathrm{lbs}$.

To crush the gray flint of 1.2 oz. weight $=2000 \mathrm{lbs}$.

To crush rolled white quartz pebble $2 \mathrm{oz} .=34,00 \mathrm{lbs}$.

B. $B$.

P.S. To-day we have summer weather. At half-past three this morning, in clear starlight, the exposed thermometer was at ... .............................................. $48^{\circ}$

At half-past seven in the morning........................ $49^{\circ}$ At half-past one in the day ................................ $60^{\circ}$ At half-past five this afternoon ........................... $54^{\circ}$

The larks and other spring birds are singing; and the yellow butterfly is in full action.

B. B.

Leighton Bussard, Feb. 10th, 1831.

XXIX. Observations on a Species of Musca Volitantes apparently existing in the Aqueous Humour of the Eye. By Thomas Batchelor, Esq.*

A MONG the numerous defects and diseases to which the $A$ component parts of the eye are subject, accidental circumstances have led me to investigate several, which appear to have their seat in the humours; and which, as far as I can learn by inquiries among medical men, are not very accurately understood. That disorder of vision, to which I shall chiefly

* Communicated by the Author.

confine 